\title{
Salmonella enterica Serovars Typhi and Paratyphi A are avirulent in newborn and infant mice even when expressing virulence plasmid genes of Salmonella Typhimurium
}

\author{
Javier Santander M. and Roy Curtiss III \\ The Biodesign Institute, Centre for Infectious Diseases and Vaccinology. Arizona State University, Tempe, Arizona
}

\begin{abstract}
Background: Salmonella enterica serovars Typhi and Paratyphi A are human host-restricted pathogens. Therefore, there is no small susceptible animal host that can be used to assess the virulence and safety of vaccine strains derived from these Salmonella serovars. However, infant mice have been used to evaluate virulence and colonization by another human host-restricted pathogen, Vibrio cholerae. Methodology: The possibility that infant mice host could be adapted for Salmonella led us to investigate the susceptibility of newborn and infant mice to oral infection with S. Typhi and S. Paratyphi A. Salmonella enterica serovar Typhimurium causes enteric fever in adult mice and this system has been used as a model for human typhoid. The pSTV virulence plasmid, not present in S. Typhi and S. Paratyphi A, plays an essential role in S. Typhimurium colonization and systemic infection of mice. We also conjugated pSTV into S. Typhi and S. Paratyphi A serovars and evaluated these transconjugants in newborn and infant mice.

Results: We determined that the spv virulence genes from the S. Typhimurium virulence plasmid are expressed in S. Typhi and S. Paratyphi A in a RpoS dependent fashion. Also, we determined that S. Typhi and S. Paratyphi A with and without pSTV transiently colonize newborn and infant mice tissues.

Conclusion: Newborn and infant mice infected with S. Typhi and S. Paratyphi A do not succumb to the infection and that carriage of the S. Typhimurium virulence plasmid, pSTV, did not influence these results.
\end{abstract}

Key words: Salmonella Typhi; Salmonella Paratyphi A; newborn mice, infant mice; virulence plasmid

J Infect Dev Ctries 2010; 4(11):723-731.

(Received 19 May 2010- Accepted 20 October 2010)

Copyright (ㄷ 2010 Santander and Curtiss. This is an open-access article distributed under the Creative Commons Attribution License, which permits unrestricted use, distribution, and reproduction in any medium, provided the original work is properly cited.

\section{Introduction}

Typhoid and paratyphoid fever are severe human diseases caused by $S$. Typhi and $S$. Paratyphi A respectively, with an estimated 16 million cases resulting in more than 600,000 deaths annually $[1,2]$. Both $S$. Typhi and $S$. Paratyphi A are human hostrestricted pathogens. The pathogenesis of typhoid and paratyphoid are poorly understood, in part due to the lack of a susceptible animal host that exhibits the same clinical signs as human infections. Attenuated $S$. Typhi strains have been used as live vectors to deliver foreign antigens either by expressing antigens or by delivering the antigen-encoding genes on eukaryotic expression plasmids $[3,4,5]$. The absence of an inexpensive, small animal host for pre-clinical evaluation of vaccine candidates is an obstacle to developing live attenuated $S$. Typhi vaccines. Chimpanzees infected with wild-type $S$. Typhi Ty2 produced a mild clinical illness that resembled human typhoid fever, but only when given in a high dose $\left(1 \times 10^{11} \mathrm{CFU}\right)$ [6]. This host is not convenient for high through-put analyses due to the high cost and scarcity of supply. In addition, since a high inoculum of wild-type is needed to cause clinical infection, this is not an ideal host for evaluating the virulence potential of attenuated strains [7].

$S$. Typhi and $S$. Paratyphi A are unable to induce progressive disease in adult BALB/c mice challenged orally or parenterally with high doses $\left(>10^{9}\right.$ orally; $10^{7}$ to $10^{8}$ parenterally) $[8,9,10,11,12]$. The current method for assessing the safety of $S$. Typhi vaccines consists of inoculating mice intraperitoneally with moderated doses ( $>10^{3} \mathrm{CFU}$ ) of $S$. Typhi suspended in hog gastric mucin [7]. However, death of the mice is believed to result from the toxic effects of endotoxin associated with the rapidly expanding peritoneal population of $S$. Typhi $[13,14,15]$. In addition, the attenuating effects of some mutations cannot be discerned by this method [16]. The use of other animal hosts, such as rabbits and pigs, has also 
been explored, but these animals were found to be no more useful than mice $[17,18]$. However, intranasal inoculation of mice has been used successfully to evaluate the immune responses to foreign antigens expressed by $S$. Typhi recombinant vaccines $[19,20]$.

$S$. Typhimurium, the causative agent of enterocolitis infection in humans and cattle, causes a lethal systemic disease in susceptible mice that resembles human typhoid infection [21,22]. The mouse assay has been adopted and extensively used to study pathogenesis and immunity of typhoid fever. However, a shortcoming of this assay is the fact that $S$. Typhimurium does not cause typhoid fever in humans, suggesting that genetic differences between $S$. Typhi and $S$. Typhimurium are critically important for the disease outcome in both mice and humans. Whole-genome sequencing has revealed genome degradation in host-restricted Salmonella serotypes [23]. Therefore, the evolution from a broad host range serovar such as Typhimurium, to hostrestricted serovars such as Typhi and Paratyphi A, may have occurred by genome degradation $[21,23]$. In addition, not all the information obtained using the $S$. Typhimurium mouse assay can be directly applied to improve understanding of typhoid fever since some of the virulence factors of $S$. Typhimurium such as Salmonella virulence plasmid pSTV, required for invasion of host tissues [24,25], are absent in $S$. Typhi and $S$. Paratyphi A [23,26,27,28].

Nevertheless, infant mice have been used to measure the median lethal dose $\left(\mathrm{LD}_{50}\right)$ as a parameter for disease production by Vibrio cholerae and other host-restricted bacterial strains [29,30,31] and therefore may be useful in developing a systemic infection model for $S$. Typhi and $S$. Paratyphi A, since adult mice are resistant to those pathogens [10]. In this study, the colonization and pathogenesis potential of $S$. Typhi and $S$. Paratyphi A in newborn and infant mice was evaluated. Newborn and infant mice were observed to be colonized by $S$. Typhi and $S$. Paratyphi A, but were tolerant of the infection. In addition, whether $S$. Typhi and $S$. Paratyphi A carrying and expressing the $S$. Typhimurium virulence plasmid were able to better infect and colonize newborn and infant mice was evaluated.

\section{Methodology}

Bacterial strains and culture conditions

The bacterial strains and plasmids used in this study are listed in Table 1. Bacteriological media and components were from Difco (Franklin Lakes, NJ). Antibiotics and reagents were from Sigma (St. Louis,
$\mathrm{MO})$. Salmonella strains were grown at $37^{\circ} \mathrm{C}$ in either buffered magnesium minimal medium $\mathrm{pH} 5.5$ $(\mathrm{MgM})$ [32] or LB medium [33]. For plates, media was solidified with $1.5 \%$ (wt/vol) agar. When required, medium was supplemented with tetracycline (tet; $12.5 \mu \mathrm{g} / \mathrm{ml}$ ), L-cysteine- $\mathrm{HCl}$ (cys; $22 \mu \mathrm{g} / \mathrm{ml}$ ), DL-tryptophan (trp; $20 \mu \mathrm{g} / \mathrm{ml}$ ) and Lhistidine- $\mathrm{HCl}$ (his; $22 \mu \mathrm{g} / \mathrm{ml}$ ). Buffered saline with gelatin (BSG) [34] was used as a diluent and to suspend bacteria prior to inoculation of mice.

\section{Beta-galactosidase assays}

Expression of $s p v R-l a c Z$ and $s p v A-l a c Z$ fusions in $\operatorname{RpoS}^{+}$and $\operatorname{RpoS}^{-} S$. Typhi was determined by $\beta$ galactosidase activity assay [35]. Strains were transformed with pGTR72 (spvR-lacZ, operon fusion), pGTR90 (spvA-lacZ, operon fusion) or pGTR75 (tet-lacZ operon fusion control) [36] and grown in MgM medium to stationary phase. The $s p v$ operon is up-regulated under conditions that mimic the Salmonella containing vacuole (SCV) [33]. MgM media was used for this experiment because it mimics the environment of SCV [37].

Construction and characterization of S. Typhi and $\mathrm{S}$. Paratyphi A carry pSTV

$S$ Typhi and $S$. Paratyphi A strains harboring the $S$. Typhimurium virulence plasmid were constructed by conjugation on minimal media [38]. Plasmid pStSR101 is a Tnmini-tet-labeled virulence plasmid derivative, which can restore the full virulence of pSTV-cured strains of $S$. Typhimurium [25]. Like the wild-type virulence plasmid, it is self-transmissible [38]. S. Typhimurium $\chi 3351$ SL1344 hisG carrying pStSR101 was used as the donor. Conjugation was performed in M9 minimal media agar [39], supplemented with cys, trp, and his. Selection was performed on M9 media supplemented with cys, trp and tet to select for $S$. Typhi and $S$. Paratyphi A transconjugants and against the histidine-requiring $S$. Typhimurium donor. Transconjugants were characterized for LPS, Vi antigen ( $S$. Typhi), biochemical properties, and nutritional requirements as described [39] and were found to exhibit the expected phenotypes (Table 1). The stability of pStSR101 in $S$. Typhi and $S$. Paratyphi A was determined essentially as described by Konjufca et al. [40], except that strains were grown in the absence of tetracycline for fifty generations, at which point cells were plated onto LB agar and individual colonies were screened for tetracycline resistance. 
Table 1. Salmonella strains and relevant characteristics

\begin{tabular}{|c|c|c|c|}
\hline Strain & Relevant characteristics & Origin & $\begin{array}{l}\text { Source or } \\
\text { reference }\end{array}$ \\
\hline$\chi 3744$ S. Typhi ISP1820 & $\begin{array}{l}\text { Wild-type, } \mathrm{RpoS}^{+}, \mathrm{Cys}^{-}, \mathrm{Trp}^{-}, \mathrm{OD}_{1}: \mathrm{H}_{\mathrm{d}}:-: \mathrm{Vi}, \mathrm{V} \& \\
\text { V/W form }\end{array}$ & Wild-type & 41 \\
\hline$\chi 3744$ S. Typhi ISP1820 (pStSR101) & $\begin{array}{l}\text { Wild-type } \mathrm{RpoS}^{+}, \mathrm{Cys}^{-}, \mathrm{Trp}^{-}, \mathrm{OD}_{1}: \mathrm{H}_{\mathrm{d}}:-: \mathrm{Vi}, \mathrm{V} \& \\
\text { V/W form, } \mathrm{Tet}^{\mathrm{r}}\end{array}$ & $\chi 3744$ & This study \\
\hline ఒ3761 S. Typhimurium UK-1 & $\mathrm{RpoS}^{+}, \mathrm{pSTV}, \mathrm{OB}_{1}: \mathrm{H}_{\mathrm{i}}: \mathrm{H}_{2}:-$ & Wild-type & 42 \\
\hline$\chi 3769$ S. Typhi Ty2 & Wild-type, $\mathrm{RpoS}^{-}, \mathrm{Cys}^{-}, \mathrm{OD}_{1}: \mathrm{H}_{\mathrm{d}:-: \mathrm{Vi}, \mathrm{V} \text { form }}$ & Wild-type & 43 \\
\hline ఒ3769 S. Typhi Ty2 (pStSR101) & Wild-type, $\mathrm{RpoS}^{-}, \mathrm{Cys}^{-}, \mathrm{OD}_{1}: \mathrm{H}_{\mathrm{d}}:-: \mathrm{Vi}, \mathrm{V}$ form, $\mathrm{Tet}^{\mathrm{r}}$ & $\chi 3769$ & This study \\
\hline$\chi 8219$ S. Paratyphi A & RpoS ${ }^{+}$, Cryptic plasmid pSPA1, OA:H $\mathrm{H}_{\mathrm{a}}:-:-$ & Wild-type & ATCC 9281 \\
\hline$\chi 8387$ S. Paratyphi A & RpoS ${ }^{+}$, Cryptic plasmid cured, OA: $\mathrm{H}_{\mathrm{a}}:-:-$ & $\chi 8219$ & This study \\
\hline$\chi 8387$ S. Paratyphi A (pStSR101) & $\mathrm{RpoS}^{+}, \mathrm{OA}: \mathrm{H}_{\mathrm{a}}:-:-, \mathrm{Tet}^{\mathrm{r}}$ & $\chi 8387$ & This study \\
\hline$\chi 8438 S$. Typhi Ty2 & $\mathrm{RpoS}^{+}, \mathrm{Cys}^{-}, \mathrm{OD}_{1}: \mathrm{H}_{\mathrm{d}}:-: \mathrm{Vi}, \mathrm{V} \& \mathrm{~V} / \mathrm{W}$ form & $\chi 3769$ & 41 \\
\hline 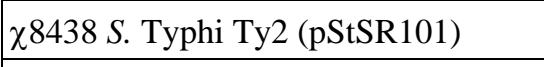 & $\mathrm{RpoS}^{+}, \mathrm{Cys}^{-}, \mathrm{OD}_{1}: \mathrm{H}_{\mathrm{d}}:-: \mathrm{Vi}, \mathrm{V} \& \mathrm{~V} / \mathrm{W}$ form, $\mathrm{Tet}^{\mathrm{r}}$ & $\chi 8438$ & This study \\
\hline ఒ8740 S. Typhi CT18 & $\mathrm{RpoS}^{+}, \mathrm{Vi}^{-}, \mathrm{OD}_{1}: \mathrm{H}_{\mathrm{d}}:-:-, \mathrm{W}$ form & Wild-type & 27 \\
\hline 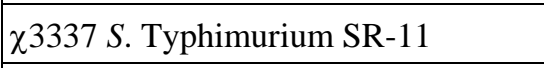 & $\mathrm{RpoS}^{+}$, gyrA1816, $\mathrm{pSTV}^{-}, \mathrm{OB}_{1}: \mathrm{H}_{\mathrm{i}}: \mathrm{H}_{2}:-$ & $\chi 3306$ & 25 \\
\hline $\begin{array}{l}\chi 3351 S . \text { Typhimurium SL-1344 } \\
\text { (pStSR101) }\end{array}$ & $\mathrm{RpoS}^{+}, r p s L, h i s G, \mathrm{Tet}^{\mathrm{r}}, \mathrm{OB}_{1}: \mathrm{H}_{\mathrm{i}}: \mathrm{H}_{2}:-$ & $\chi 3340$ & 25 \\
\hline \multicolumn{4}{|l|}{ Plasmids } \\
\hline pGTR72 & spvR-lacZ,cat & & 44 \\
\hline pGTR90 & spvA-lacZ,cat & & 44 \\
\hline pGTR75 & $\begin{array}{l}\text { spvR::lacZ,cat cat, same as pGTR72, except the } \\
\text { lacZ,cat is inserted in opposite orientation, under } \\
\text { control of tet promotor of the plasmid }\end{array}$ & & 44 \\
\hline pSTV & $s p v R A B C D, p e f B A C D, r c k$ & & 25 \\
\hline pStSR101 & spvRABCD, pefBACD, rck, Tnmini-tet- & & 25 \\
\hline
\end{tabular}

Reverse Transcriptase-PCR

Expression of $s p v R$ and $s p v A$ in $S$. Typhi and $S$. Paratyphi A from pStSR101 was evaluated by RTPCR. Total RNA extraction was performed by RNeasy QIAgene kit (Hilden, Germany) from strains grown in $\mathrm{MgM}$ media at $37^{\circ} \mathrm{C}$ to stationary phase $[33,37]$. Reverse transcription and PCR was performed using the one-step RT-PCR QIAgene kit. Specific primers were used for the $s p v R$ (5'GGAAACAGGTTCCTTCAGTATCGC-3' and 5'TATTTGGCTGTTAACGGCTCTCCC-3') (size of the $s p v R$ amplified fragment: $349 \mathrm{bp}$ ) and $s p v A\left(5^{\prime}-\right.$ TTGTCCGTCAGACCCGTAAACAGT-3' and 5'TCTTCCAGCGACACATCGGTATT CAG-3') (size of the spvA amplified fragment: $358 \mathrm{bp})$ genes. $16 \mathrm{~S}$ rRNA primers were used as control of expression (5'ACTGGCAGGCTTGAGCTTGTAGA-3' and 5'AAGGGCACAACCTCCAAGTA GACA-3') (size of the $16 S$ rRNA amplified fragment: $158 \mathrm{bp}$ ).

\section{Animal experiments}

BALB/c newborn and infant mice (Charles River Laboratories, Wilmington, MA) were bred and maintained at $22^{\circ} \mathrm{C}$ to $23^{\circ} \mathrm{C}$ with 12 hours of illumination daily. Mice older than two weeks were separated from their mothers 4 hours before infection and fed with regular food. Bacterial strains were grown overnight in standing cultures that were 
diluted 1:100 in prewarmed LB broth and grown with mild aeration to an $\mathrm{OD}_{600}$ of 0.8 to 0.9 . Bacteria were sedimented by centrifugation at room temperature and resuspended in BSG to densities appropriate for the inoculation route and dose. Newborn mice (3 to 24 hours) and infant mice (48 hours to 3 weeks old) were challenged with $\sim 10^{9} \mathrm{CFU}$ of $S$. Typhi, $S$. Paratyphi A, or $S$. Typhimurium. Ten microliters of $\sim 10^{9}$ CFU of the bacterial strain suspended in BSG were orally administered. Intranasal inoculations consisted in $5 \mu \mathrm{l}$ of $\sim 10^{9} \mathrm{CFU}$ of the bacterial strain suspended in BSG, administered without anesthesia. Mice were euthanized via asphyxiation with $\mathrm{CO}_{2}$ and necropsied at various times. The bacterial titers in newborn mice inoculated orally were determined at 3, 7, 14 and 21 days post oral infection. Spleen, liver, and the intestines were collected and washed with BSG until homogenization. The homogenizer (Brinkman, Westburg, NY) was washed with 5\% Amphyl, followed by a wash with $70 \%$ ethanol, followed by two washes with $\mathrm{dH} 2 \mathrm{O}$. Homogenized tissues were plated onto MacConkey agar plates supplemented with $1 \%$ lactose to determine the number of viable bacteria. Salmonella colonies were white on the MacConkey plates. Isolated colonies were further identified by agglutination with Salmonella specific antiserum (Table 1) and antibiotic resistance marker.

Table 2. Infection of newborn and infant mice with $S$. Typhi and $S$. Paratyphi A.

\begin{tabular}{|l|c|c|c|c|}
\hline \multicolumn{1}{|c|}{ Strain } & $\begin{array}{c}\text { Inoculating dose } \\
(\text { CFU) }\end{array}$ & Mice age & Survivors/total & Route \\
\hline$\chi 3744$ S. Typhi ISP1820 & $1.1 \times 10^{9}$ & 3 weeks & $5 / 5$ & oral \\
\hline & $1.1 \times 10^{9}$ & 1 week & $7 / 7$ & oral \\
\hline & $1.1 \times 10^{9}$ & $<24 \mathrm{~h}$ & $6 / 6$ & oral \\
\hline$\chi 3769$ S. Typhi Ty2 $\left(\mathrm{RpoS}^{-}\right)$ & $1.1 \times 10^{9}$ & 1 week & $7 / 7$ & intranasal \\
\hline$\chi 8438$ S. Typhi Ty2 $\left(\mathrm{RpoS}^{+}\right)$ & $1.1 \times 10^{9}$ & $<24 \mathrm{~h}$ & $5 / 5$ & oral \\
\hline$\chi 8740$ S. Typhi CT18 & $1.5 \times 10^{9}$ & $<24 \mathrm{~h}$ & $4 / 4$ & oral \\
\hline$\chi 8387 S$. Paratyphi A & $1.0 \times 10^{9}$ & $<24 \mathrm{~h}$ & $8 / 9$ & oral \\
\hline & $1.1 \times 10^{9}$ & $<24 \mathrm{~h}$ & $8 / 8$ & oral \\
\hline$\chi 3337$ S. Typhimurium SR-11 & $1.1 \times 10^{9}$ & 1 week & $9 / 9$ & intranasal \\
\hline & $2.1 \times 10^{9}$ & 3 weeks & $0 / 5$ & oral \\
\hline
\end{tabular}

Newborn: $3 \mathrm{~h}$ to $24 \mathrm{~h}$ after birth. Infant: $48 \mathrm{~h}$ to 3 weeks old. Mice were observed for $4-5$ weeks. $\chi 3337 \mathrm{~S}$. Typhimurium pSTV-cured was used as positive control.

\section{Statistics}

Mann-Whitney U Test (version 5.0; GraphPad Software, Inc.) was used for comparing the expression of spv-lacZ fusions.

\section{Results}

Virulence and colonization of $\mathrm{S}$. Typhi and $\mathrm{S}$. Paratyphi A in newborn and infant mice

Newborn and infant mice infected orally with $S$. Typhi and $S$. Paratyphi A survived without any symptoms of disease, while the mice inoculated with a $S$. Typhimurium strain cured of plasmid pSTV succumbed to the infection (Table 2). Infant mice, one to three weeks of age, and newborn mice infected intranasally with $S$. Typhi and $S$. Paratyphi A strains also survived without any symptoms of disease (Table 2). The bacterial titers in newborn mice inoculated orally were determined at 3, 7, 14 and 21 days post infection. Spleen, liver, and the intestines were collected and the number of viable bacteria was determined. S. Typhi $\operatorname{RpoS}^{+}$and $S$. Paratyphi A $\mathrm{RpoS}^{+}$were able to colonize the intestines for three weeks (Figure 1A). S. Typhi Ty2 $\mathrm{RpoS}^{-}$was less able to persist in the intestines and cleared after one week. $S$. Typhi and $S$. Paratyphi A were able to colonize the spleen and liver of infected mice and the RpoS- strain Ty2 was more effectively cleared than the $\mathrm{RpoS}^{+}$ strains (Figures 1B and 1C). These results are consistent with a report that $r p o S S$. Typhimurium mutants are less persistent in mice than their wild- 
type $\mathrm{RpoS}^{+}$parent strains $[41,45]$. Taken together, these results show that although wild-type $S$. Typhi and $S$. Paratyphi A can transiently colonize young mice, they are not capable of establishing a disseminating infection.

Table 3. Infection of newborn and infant mice with $S$. Typhi pStSR101 and $S$. Paratyphi A pStSR101.

\begin{tabular}{|l|c|c|c|c|}
\hline \multicolumn{1}{|c|}{ Strain } & $\begin{array}{c}\text { Inoculating } \\
\text { dose (CFU) }\end{array}$ & Mice age & Survivors/total & Route \\
\hline$\chi 3744$ S. Typhi ISP1820 (pStSR101) & $1.2 \times 10^{9}$ & $<24 \mathrm{~h}$ & $6 / 6$ & oral \\
\hline$\chi 3769$ S. Typhi Ty2 (pStSR101) & $1.1 \times 10^{9}$ & $<24 \mathrm{~h}$ & $7 / 7$ & intranasal \\
\hline$\chi 8387$ S. Paratyphi A (pStSR101) & $1.2 \times 10^{9}$ & $<24 \mathrm{~h}$ & $5 / 5$ & oral \\
\hline & $1.1 \times 10^{9}$ & $<24 \mathrm{~h}$ & $10 / 10$ & oral \\
\hline$\chi 3351$ S. Typhimurium SL-1344 (pStSR101) & $1.1 \times 10^{9}$ & $<24 \mathrm{~h}$ & $7 / 7$ & intranasal \\
\hline & $1.8 \times 10^{9}$ & 3 weeks & $0 / 5$ & oral \\
\hline
\end{tabular}

Newborn: $3 \mathrm{~h}$ to $24 \mathrm{~h}$ after birth. Infant: $48 \mathrm{~h}$ to 3 weeks old. Mice were observed between $4-5$ weeks. $\chi 3351 S$. Typhimurium (pStSR101) was used as positive control.

Figure 1. Colonization of $S$. Typhi and S. Paratyphi A with and without pStSR101 virulence plasmid in newborn mice $<24 \mathrm{~h}$ old. A-C. Newborn mice orally infected with Salmonella without pStSR101; D-F. Newborn mice orally infected with Salmonella harboring pStSR101; A, D. Intestine colonization; B, E. Spleen colonization; C, F. Liver colonization. Each point represents the average between 4 animal tissues.

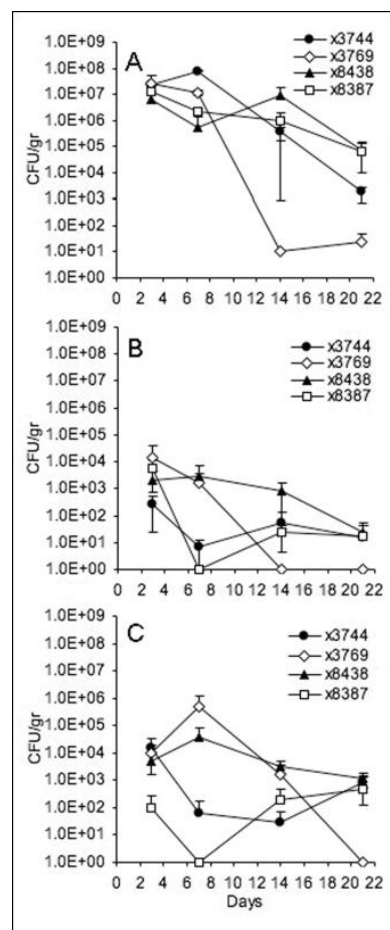

Expression of spv genes in S. Typhi RpoS ${ }^{+}$and RpoS

The $S$. Typhimurium virulence plasmid is required for colonization of mouse tissues [24]. An investigation into whether the addition of the virulence plasmid to $S$. Typhi and $S$. Paratyphi A

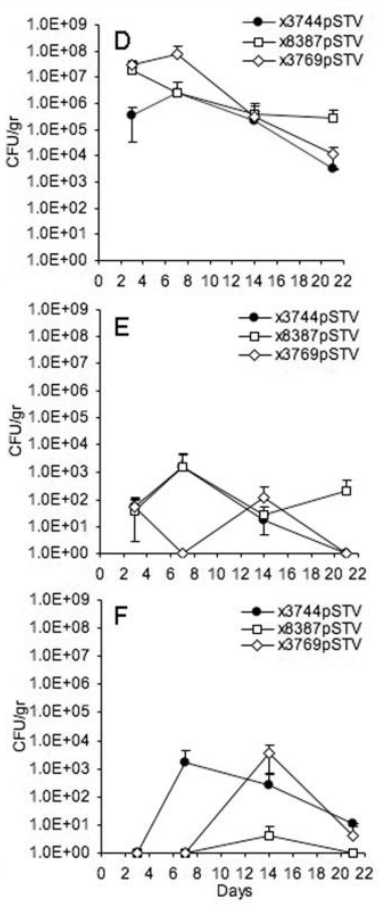

could enhance their ability to colonize young mice was conducted. One virulence plasmid operon that is critical for host invasion is encoded in the $s p v$ region $[24,33,46]$. The $s p v$ region consists of five genes, $s p v R A B C D$ which are all transcribed in the same 
direction [46]. The $s p v R$ gene encodes $\mathrm{SpvR}$, which activates the transcription of both the $s p v R$ and spvABCD transcriptional units [12,47,48]. In addition, the sigma factor RpoS is also required for maximum expression of the operon [49,50,51,52].

Because of the central role of $s p v$ in tissue colonization, expression of $s p v R-l a c Z$ and $s p v A-l a c Z$ fusions in $\mathrm{RpoS}^{+}$and $\mathrm{RpoS}^{-} S$. Typhi by $\beta$ galactosidase activity were compared to establish that these genes were able to be transcribed in $S$. Typhi and that transcription is dependent upon RpoS. [35]. The $\operatorname{RpoS}^{+} S$. Typhi strains produced $\beta$-galactosidase levels comparable to the $S$. Typhimurium $\mathrm{RpoS}^{+}$ control for both fusions (Figures 2A and 2B). In contrast, reduced expression was observed for $S$. Typhi Ty2, which has a defective $r p o S$ allele due to a frame-shift mutation at nucleotide 993 [53]. These results indicate that $S$. Typhi is able to transcribe the $s p v$ genes to the same levels as $S$. Typhimurium and confirm that maximum $s p v$ expression requires RpoS. Stability and expression of pSTV plasmid in S. Typhi and S. Paratyphi A

A tetracycline-marked derivative of the $S$. Typhimurium virulence plasmid, pStSR101 [24], was moved into the $S$. Typhi and $S$. Paratyphi A strains. Because these host-restricted strains do not normally carry this plasmid, it is possible that the plasmid may not be maintained for enough generations to colonize a mouse. Therefore, the stability of pStSR101 in $S$. Typhi and $S$. Paratyphi A was examined. The pStSR101 virulence plasmid was stably maintained for 50 or more generations in all $S$. Typhi and $S$. Paratyphi A strains. In addition, whether the $s p v$ genes were transcribed from this plasmid was evaluated. RT-PCR products were detected in all strains harboring pStSR101 (Figure 3), indicating that the $s p v$ genes are transcribed in $S$. Typhi and $S$. Paratyphi A.

Figure 2. Evaluation of $s p v R$ and $s p v A$ expression in $S$. Typhi by $\beta$-galactosidase assay. A. Evaluation of $s p v R$; B. Evaluation of spvA; C. Control. $\chi 3769$ S. Typhi Ty2 RpoS ; $\chi 3744$ S. Typhi ISP1820 RpoS $; \chi 3337$ S. Typhimurium SR-11 RpoS ; strains harboring the respective plasmids; the strains where grown in MgM media to stationary growth phase. $* P<0.01$ for the $\mathrm{RpoS}^{+}$strains compared with RpoS ${ }^{-}$strain, significant differences are indicated.

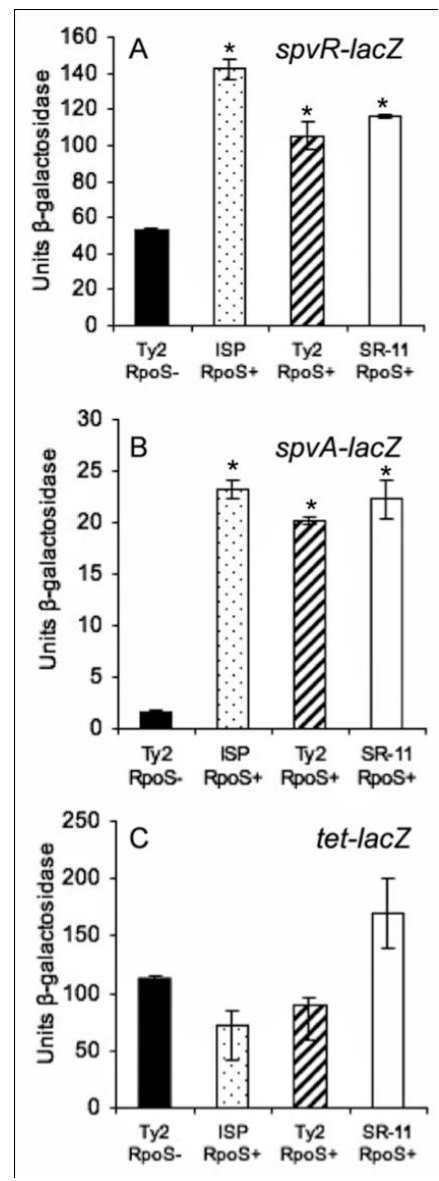


Virulence and colonization of S. Typhi and S. Paratyphi A harboring pSRSt101 in newborn and infant mice

The effect of the $S$. Typhimurium virulence plasmid on the ability of $S$. Typhi and $S$. Paratyphi A to cause disease in newborn and infant mice was evaluated. When newborn and infant mice were orally inoculated with $S$. Typhi and $S$. Paratyphi A harboring pStSR101, they survived without any disease symptoms, whereas all the mice inoculated with $S$. Typhimurium died (Table 3). Infant mice and newborn mice infected intranasally with $S$. Typhi or $S$. Paratyphi A carrying pStSR101 also survived without any symptoms of disease (Table 3 ).

The presence of pStSR101 did not enhance the ability of $S$. Typhi and $S$. Paratyphi A to colonize infant mice (Figure 1). Unexpectedly, the presence of pStSR101 in $S$. Typhi Ty2 $\mathrm{RpoS}^{-}$resulted in a slight increase in persistence in the intestines compared to the plasmid-free strain (Figures 1A and 1D), indicating that there may be a virulence plasmid gene(s) that can complement the defect in intestinal colonization imparted by the $\mathrm{RpoS}^{-}$phenotype. Recently, it has been reported that $\mathrm{pP}_{\mathrm{ST} 98}$, a promiscuous $\mathrm{R}$ plasmid found in a multi-drug resistant isolate of $S$. Typhi from Asia, carries the $s p v$ region. This plasmid confers antibiotic resistance and increases virulence in mice when transferred to $\mathrm{pSTV}^{-} S$. Typhimurium [54]. While it is possible that $s p v$ genes may confer an enhancement of virulence in human hosts, our results indicate that they have no effect on infant mouse colonization in wild-type $S$. Typhi.

\section{Discussion}

In summary, these results show that $S$. Typhi and $S$. Paratyphi A can transiently colonize young mice, but cannot establish a lethal infection. The $s p v$ genes are transcribed in $S$. Typhi and $S$. Paratyphi A and a functional rpoS gene is required for maximum expression. However, the virulence plasmid does not enable $S$. Typhi or $S$. Paratyphi A to establish a lethal infection in newborn or infant mice.

Figure 3. Expression of $s p v R$ and $s p v A$ evaluated by RT-PCR (agarose gel 1\%). 1. $\chi 3769$ S. Typhi Ty2; 2. $\chi 3744$ S. Typhi ISP1820; 3. $\chi 8387$ S. Paratyphi A; 4. $\chi 3769$ S. Typhi Ty2 (pStSR101); 5. $\chi 3744$ S. Typhi ISP1820 (pStSR101); 6. $\chi 8387 S$. Paratyphi A (pStSR101); 7. $\chi 3351 S$. Typhimurium SL-1344 (pStSR101); 8. $\chi 3761 S$. Typhimurium UK-1 pSTV $;$ 16S: 16S $(r r n A)$ was used as positive control; DNA control: the RNA samples were used as templates in a PCR reaction to amplify the $16 S r R N A$ to detect DNA contamination.

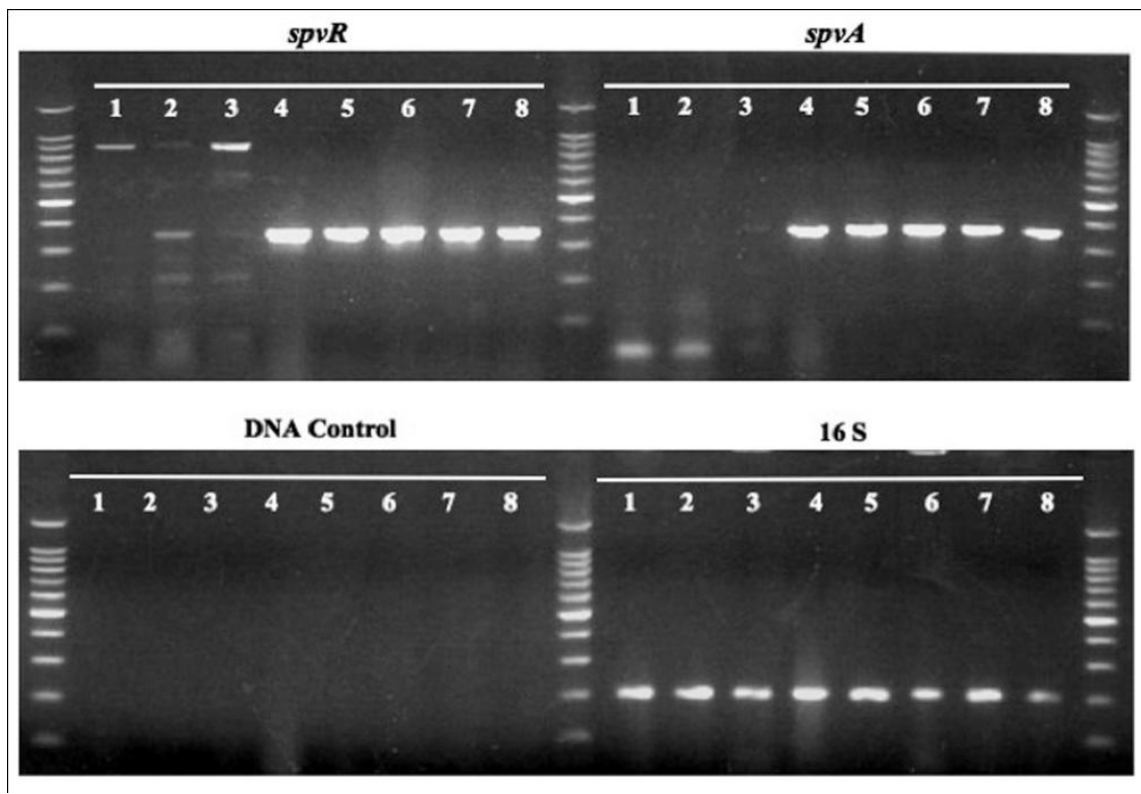




\section{Acknowledgments}

This work was supported by grants from the National Institutes of Health (AI24533, AI057885, AI056289) and the Bill and Melinda Gates Foundation (\#37863 and CONICYT), Chile, through Gestión Propia Fellowship.

We are grateful to Dr. Paul Gulig (University of Florida, USA) for providing the pGTR73, pGTR75 and pGRT90 plasmids and advice. We are particularly grateful to Dr. James Robeson (Pontifícia Universidad Católica de Valparaíso, Chile), and Dr. Kenneth Roland (Biodesign Institute at Arizona State University, USA) for their suggestions.

\section{References}

1. Parry CM, Hien TT, Dougan G, White NJ, Farrar JJ (2002) Typhoid fever. N Engl J Med 2002; 347: 1770-1782.

2. Sood S, Kapil A, Dash N, Das BK, Goel V, Seth P (1999) Paratyphoid fever in India: An emerging problem. Emerg Infect Dis 5: 483-484.

3. Curtiss R III (2005) Antigen delivery systems: Development of live recombinant attenuated bacterial antigen and DNA vaccine delivery vector vaccines. In: Mestecky J, Bienenstock J, Lamm ME, Mayer L, McGhee JR, Strober W, editors. Mucosal Immunology, 3rd edition, Academic Press, New York, 1009-1037.

4. Dietrich G, Spreng S, Gentschev I, Goebel W (2000) Bacterial systems for the delivery of eukaryotic antigen expression vectors. Antisense Nucleic Acid Drug Dev 10: 391-399.

5. Garmory HS, Brown KA, Titball RW (2002) Salmonella vaccines for use in humans: present and future perspectives. FEMS Microbiol Rev 26: 339-353.

6. Edsall G, Gaines S, Landy M, Tigertt WD, Sprinz H, Trapani RJ, Mandel AD, Benenson AS (1960) Studies on infection and immunity in experimental typhoid fever. I. Typhoid fever in chimpanzees orally infected with Salmonella typhosa. J Exp Med 112: 143-166.

7. Pasetti MF, Levine MM, Sztein MB (2003) Animal models paving the way for clinical trials of attenuated Salmonella enterica serovar Typhi live oral vaccines and live vectors. Vaccine 21: 401-418.

8. Carter PB, Collins FM (1974) Growth of typhoid and paratyphoid bacilli in intravenously infected mice. Infect Immun 10: 816-822.

9. Carter PB, Collins FM (1974) The route of enteric infection in normal mice. J Exp Med 139: 1189-1203.

10. Collins FM, Carter PB (1978) Growth of Salmonellae in orally infected germfree mice. Infect Immun 21: 41-77.

11. Gerichter CB (1960) The dissemination of Salmonella typhi, $S$. paratyphi A and S. paratyphi B through the organs of the white mouse by oral infection. J Hyg (Lond) 58: 307-319.

12. Sheehan BJ, Dorman CJ (1998) In vivo analysis of the interactions of the LysR-like regulator $\mathrm{SpvR}$ with the operator sequences of the $s p v A$ and $s p v R$ virulence genes of Salmonella typhimurium. Mol Microbiol 30: 91-105.

13. Nugester WJ, Jourdonais LF, Wolf AA (1936) The effect of mucin on infections by bacteria. J Infect Dis 1936: 59:11.

14. Powell CJ Jr, DeSett CR, Lowenthal JP, Berman S (1980) The effect of adding iron to mucin on the enhancement of virulence for mice of Salmonella typhi strain TY2. J Biol Stand 8: 79-85.

15. Spaun J (1964) Studies on the influence of the route of immunization in the active mouse protection test with intraperitoneal challenge for potency assay of typhoid vaccines. Bull. World Health Organ 31: 793-798.

16. Baker SJ, Daniels C, Morona R (1997) PhoP/Q regulated genes in Salmonella typhi identification of melittin sensitive mutants. Microb Pathog 1997 22: 165-179.

17. Gilman RH, Young C, Bulger R, Hornick RB, Greenberg B (1982) Anatomical and immunological responses of rabbit gallbladders to bacterial infections. Infect Immun 36: 407416.

18. Metcalf ES, Almond GW, Routh PA, Horton JR, Dillman RC, Orndorff PE (2000) Experimental Salmonella typhi infection in the domestic pig, Sus scrofa domestica. Microb Pathog 29: 121-126.

19. Galen JE, Gomez-Duarte OD, Losonsky GA, Halpern JL, Lauderbaugh CS, Kaintuck S, Reymann MK, Levine MM (1997) A murine model of intranasal immunization to assess the immunogenicity of attenuated Salmonella typhi live vector vaccines in stimulating serum antibody responses to expressed foreign antigens. Vaccine 15: 700-708.

20. Pickett TE, Pasetti MF, Galen JE, Sztein MB, Levine MM (2000) In vivo characterization of the murine intranasal model for assessing the immunogenicity of attenuated Salmonella enterica serovar Typhi strains as live mucosal vaccines and as live vectors. Infect Immun 68: 205-213.

21. Bäumler AJ, Tsolis RM, Ficht TA, Adams LG (1998) Evolution of host adaptation in Salmonella enterica. Infect Immun 66: 4579-4587.

22. Jones BD, Falkow S (1996) Salmonellosis: host immune responses and bacterial virulence determinants. Annu Rev Immunol 14: 533-561.

23. McClelland M, Sanderson KE, Clifton SW, Latreille P, Porwollik S, Sabo A, Meyer R, Bieri T, Ozersky P, McLellan M, Harkins CR, Wang C, Nguyen C, Berghoff A, Elliott G, Kohlberg S, Strong C, Du F, Carter J, Kremizki C, Layman D, Leonard S, Sun H, Fulton L, Nash W, Miner T, Minx P, Delehaunty K, Fronick C, Magrini V, Nhan M, Warren W, Florea L, Spieth J, Wilson RK (2004) Comparison of genome degradation in Paratyphi A and Typhi, human-restricted serovars of Salmonella enterica that cause typhoid. Nat Genet 36: 1268-1274.

24. Fang FC, Krause M, Roudier C, Fierer J, Guiney DC (1991) Growth regulation of a Salmonella plasmid gene essential for virulence. J Bacteriol 173: 6783-6789.

25. Gulig PA, Curtiss R III (1987) Plasmid-associated virulence of Salmonella typhimurium. Infect Immun 55: 2891-2901.

26. Korpela K, Ranki M, Sukupolvi S, Makela H, Rhen M (1989) Occurrence of Salmonella typhimurium virulence plasmid-specific sequences in different serovars of Salmonella. FEMS Microbiol Lett 58: 49-54.

27. 27.Parkhill J, Dougan G, James KD, Thomson NR, Pickard D, Wain J, Churcher C, Mungall KL, Bentley SD, Holden MT, Sebaihia M, Baker S, Basham D, Brooks K, Chillingworth T, Connerton P, Cronin A, Davis P, Davies RM, Dowd L, White L, Farrar J, Feltwell T, Hamlin N, Haque A, Hien TT, Holroyd S, Jagels K, Krogh A, Larsen TS, Leather S, Moule S, O'Gaora P, Parry C, Quail M, Rutherford K, Simmonds M, Skelton J, Stevens K, Whitehead S, Barrell BS (2001) Complete genome sequence of a multiple drug resistant Salmonella enterica serovar Typhi CT18. Nature 413: 848-852.

28. Poppe C, Curtiss R III, Gulig PA, Gyles CL (1989) Hybridization studies with a DNA from the virulence region 
of the 60 Mdal plasmid of Salmonella typhimurium. Can J Vet Res 53: 378-384.

29. Chaicumpa W, Rowley D (1972) Experimental cholera in infant mice: protective effects of antibody. J Infect Dis 125: 480-485.

30. Guentzel MN, Berry LJ (1975) Motility as a virulence factor for Vibrio cholerae. Infect Immun 11: 890-897.

31. Ujiiye A, Kobari K (1970) Protective effect on infections with Vibrio cholerae in suckling mice caused by the passive immunization with milk of immune mothers. J Infect Dis 121(Suppl): S50-S55.

32. Hmiel SP, Snavely MD, Miller CG, Maguire ME (1986) Magnesium transport in Salmonella typhimurium: characterization of magnesium influx and cloning of a transport gene. J Bacteriol 168: 1444-1450.

33. Mazurkiewicz P, Thomas J, Thompson JA, Liu M, Arbibe L, Sansonetti P, Holden DW (2008) SpvC is a Salmonella effector with phosphothreonine lyase activity on host mitogen-activated protein kinases. Mol Microbiol 67: 13711383.

34. Curtiss R III (1965) Chromosomal aberrations associated with mutations to bacteriophage resistance in Escherichia coli. J Bacteriol 89: 28-40.

35. Miller JH (1972) Experiments in molecular genetics. Could Spring Harbor Laboratory, Cold Spring Harbor, New York.

36. Bertani G (1951) Studies on lysogenesis. I The mode of phage liberation by lysogenic Escherichia coli. J Bacteriol 62: 293-300.

37. Wilson JA, Doyle TJ, Gulig PA (1997) Exponential-phase expression of spvA of the Salmonella typhimurium virulence plasmid: induction in intracellular salts medium and intracellularly in mice and cultured mammalian cells. Microbiology 143: 3827-3839.

38. Ahmer BM, Tran M, Heffron F (1999) The virulence plasmid of Salmonella typhimurium is self-transmissible. J Bacteriol 181: 1364-1368.

39. Sambrook J, Russell W (2001) Molecular Cloning; A Laboratory Manual. $3^{\text {rd }}$ ed. Cold Spring Harbor Press.

40. Konjufca V, Wanda SY, Jenkins MC, Curtiss RIII (2006) A recombinant attenuated Salmonella enterica serovar Typhimurium vaccine encoding Eimeria acervulina antigen offers protection against $E$. acervulina challenge. Infect Immun 74: 6785-6796.

41. Santander J, Wanda SY, Nickerson CA, Curtiss RIII (2007) Role of RpoS in fine-tuning the synthesis of Vi capsular polysaccharide in Salmonella enterica serotype Typhi. Infect Immun 75: 1382-1392.

42. Curtiss R III, Porter SB, Munson M, Tinge SA, Hassan JO, Gentry-Weeks C, Kelly SM (1991) Nonrecombinant and recombinant avirulent Salmonella live vaccines for poultry. In: Blankenship LC, Bailey JS, Cox NA, Stern NJ, Meinersmann RJ, editors. Colonization control of human bacterial enteropathogens in poultry. Academic Press, New York, 169-198.

43. Felix A, Pitt RM (1951) The pathogenic and immunogenic activities of Salmonella typhi: in relation to its antigenic constituents. J Hyg 49: 92-110.

44. Caldwell AL, Gulig PA (1991) The Salmonella typhimurium virulence plasmid encodes a positive regulator of a plasmidencoded virulence gene. J Bacteriol 173: 7176-7185.

45. Coynault C, Robbe-Saule V, Norel F (1996) Virulence and vaccine potential of Salmonella typhimurium mutants deficient in the expression of the RpoS (sigma S) regulon. Mol Microbiol 22: 149-160.

46. Gulig PA, Caldwell AL, Chiodo VA (1992) Identification, genetic analysis and DNA sequence of a $7.8-\mathrm{kb}$ virulence region of the Salmonella typhimurium virulence plasmid. Mol Microbiol 6: 1395-1411.

47. Coynault C, Robbe-Saule V, Popoff MY, Norel F (1992) Growth phase and SpvR regulation of transcription of Salmonella typhimurium spvABC virulence genes. Microb Pathog 13: 133-143.

48. Krause M, Fang FC, Guiney DG (1992) Regulation of plasmid virulence gene expression in Salmonella dublin involves an unusual operon structure. J Bacteriol 174: 44824489.

49. Kowarz L, Coynault C, Robbe-Saule V, Norel F (1994) The Salmonella typhimurium katF (rpoS) gene: cloning, nucleotide sequence, and regulation of $s p v R$ and $s p v A B C D$ virulence plasmid genes. J Bacteriol 176: 6852-6860.

50. Nickerson CA, Curtiss R III (1997) Role of sigma factor RpoS in initial stages of Salmonella typhimurium infection. Infect Immun 65: 1814-1823.

51. Norel F, Robbe-Saule V, Popoff MY, Coynault C (1992) The putative sigma factor KatF (RpoS) is required for the transcription of the Salmonella typhimurium virulence gene $s p v B$ in Escherichia coli. FEMS Microbiol Lett. 1992; 78: 271-276.

52. Valone SE, Chikami GK, Miller VL (1993) Stress induction of the virulence proteins (SpvA, -B, and -C) from native plasmid pSDL2 of Salmonella dublin. Infect Immun 61: 705-713.

53. Robbe-Saule V, Norel F. The rpoS mutant allele of Salmonella typhi Ty2 is identical to that of the live typhoid vaccine Ty21a (1999) FEMS Microbiol Lett 170: 141-143.

54. Huang R, Wu S, Zhang X, Zhang Y (2005) Molecular analysis and identification of virulence gene on pRST98 from multi-drug resistant Salmonella typhi. Cell Mol Immunol 2: 136-140.

\section{Corresponding author}

Roy Curtiss III

The Biodesign Institute

Center for Infectious Diseases and Vaccinology

Arizona State University

PO Box 875401

1001 S. McAllister Avenue. Tempe, AZ 85287-5401

Phone: 480-727-0445

Fax: 480-727-0466

Email: rcurtiss@asu.edu

Conflict of interests: No conflict of interests is declared. 